Document downloaded from:

http://hdl.handle.net/10251/104804

This paper must be cited as:

Pitarch, M.; Navarro-Peris, E.; Gonzálvez-Maciá, J.; Corberán, JM. (2017). Experimental study of a subcritical heat pump booster for sanitary hot water production using a subcooler in order to enhance the efficiency of the system with a natural refrigerant (R290). International Journal of Refrigeration. 73:226-234. doi:10.1016/j.ijrefrig.2016.08.017

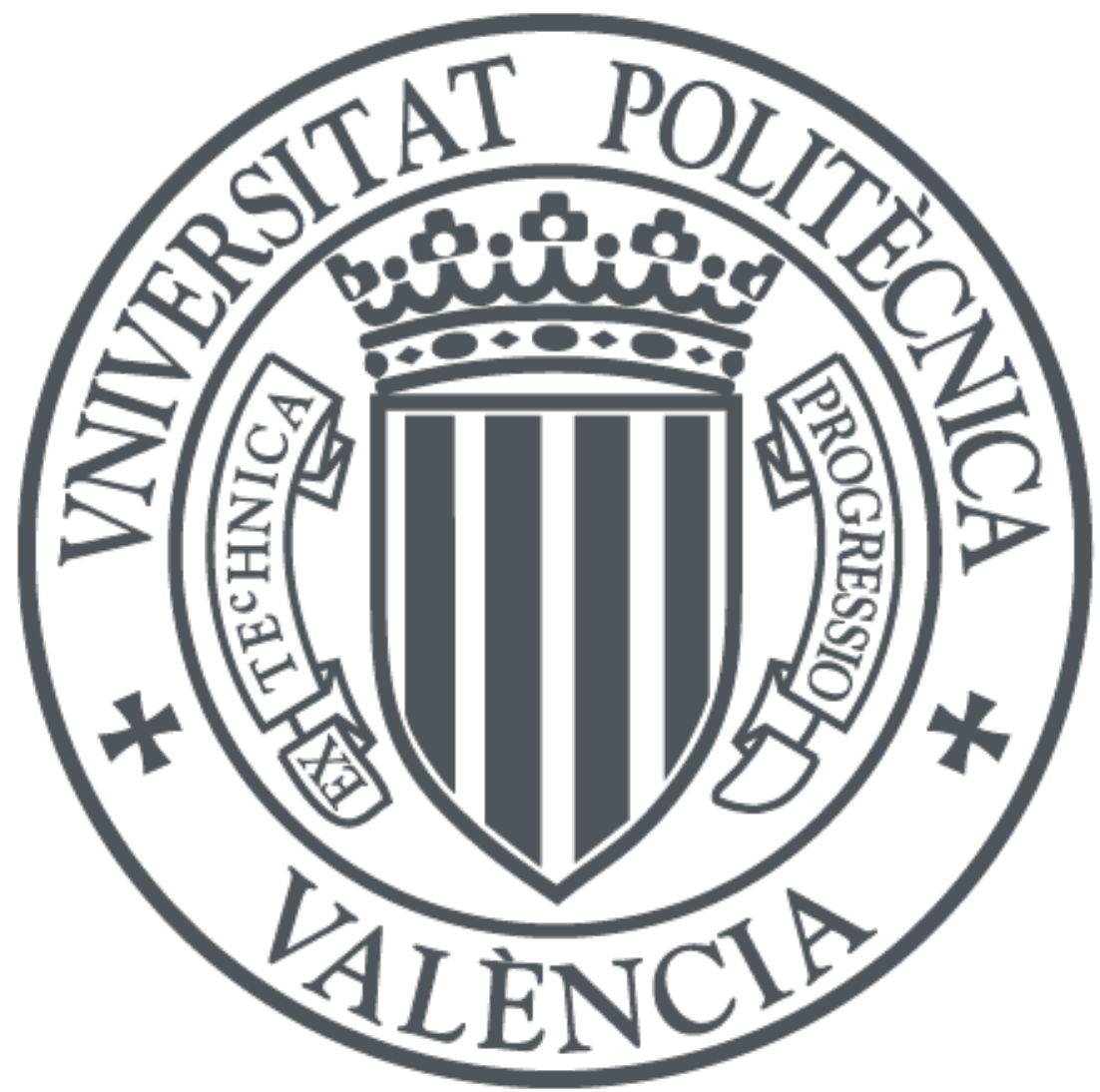

The final publication is available at

https://doi.org/10.1016/j.jirefrig.2016.08.017

Copyright Elsevier

Additional Information 


\section{Experimental study of a subcritical heat pump booster for sanitary hot water production using a subcooler in order to enhance the efficiency of the system with a natural refrigerant $(\mathbf{R} 290)$ \\ Miquel PITARCH ${ }^{(a)}$, Emilio NAVARRO-PERIS ${ }^{(a)}$, José GONZÁLVEZ-MACIÁ(a), José M. CORBERÁN ${ }^{(a)}$}

(a) Instituto de Ingeniería Energética, Universitat Politècnica de València, Camí de Vera s/n, Valencia, 46022, Spain

Tel: +34 963879123

enava@ter.upv.es

Abstract

This paper presents the experimental results obtained from a new heat pump prototype for sanitary hot water production, in the application of heat recovery from water sources like sewage water or condensation loops (typical temperature condition between $10^{\circ} \mathrm{C}$ to $30^{\circ} \mathrm{C}$ ). The system configuration is able to produce a high degree of subcooling in order to take advantage from the high water temperature glide (typical value for sanitary hot water production is $10^{\circ} \mathrm{C}$ to $60^{\circ} \mathrm{C}$ ). Subcooling is made by using a separate heat exchanger from the condenser (subcooler). The obtained results have shown a high degree of improvement by making subcooling. COP is 5.61 in nominal conditions, which is about $31 \%$ higher than the same cycle working without subcooling (Nominal point: inlet/outlet water temperature at evaporator is $20^{\circ} \mathrm{C} / 15^{\circ} \mathrm{C}$ and the water inlet/outlet temperature in the heat sink is $10^{\circ} \mathrm{C}$ and $60^{\circ} \mathrm{C}$ ).

Keywords : propane, heat pumps, natural refrigerants, sanitary hot water, subcooling 


\section{NOMENCLATURE}

BPHE: Brazed Plate Heat Exchanger

COP: Coefficient of Performance, [-]

EHPs: Electrical Heat Pumps

EU: European Union

HP: Heat Pump

HX: Heat exchanger

$\dot{m}$ : Mass flow rate

NxtHPG: Next Generation of Heat Pumps working with Natural Fluids

Q: Capacity, [kW]

Pr: Pressure ratio, [-]

Sh: Superheat, [K]

SHW: Sanitary Hot Water

SPF: Seasonal Performance Factor

T: Temperature

TEWI: Total equivalent warming impact

Subscripts

h: Heating

w: Water

w,ci: Water condenser inlet

w,co: Water condenser outlet

w,cond: water through condenser

w,ei: Water evaporator inlet

w,sub: water through subcooler

\section{INTRODUCTION}

Most residential water heaters are equipped with conventional heaters generating heat by consuming fossil fuels or electricity. Heat pump water heating systems can supply more heat just with the same amount of 
energy input used for conventional heaters (Kim et al., 2004). In this sense, an interesting alternative to the conventional Sanitary Hot Water (SHW) systems is the use of heat pump (HP) technologies, which is an application of growing interest nowadays. This potential for high efficiency is recognized by the European Directive 2009/28/CE, where a portion of the energy captured by a heat pump having an estimated average seasonal performance factor (SPF) higher than a reference value is considered as if it were obtained from renewable energy sources.

A heat pump needs a working fluid (refrigerant) in order to absorb heat from one area and reject it into another. The selected refrigerant must satisfy many requirements, like thermodynamic, safety and environmental aspects. As stated in Sarbu (2014), nowadays a new concept in the implementation of refrigeration systems is imposed, requiring tightly constructed configurations that work with refrigerants having a low TEWI (Total Equivalent Warming Impact), but keeping the performance as energetically efficient as possible. Natural refrigerants (carbon dioxide - $\mathrm{CO}_{2}(\mathrm{R} 744)$, hydrocarbons (HCs), and ammonia - $\mathrm{NH} 3$ (R717)) are pointed out as harmless to the ozone layer, with no influence upon greenhouse effect or very less than traditional refrigerants.

Between the natural refrigerants, the use of $\mathrm{CO}_{2}$ working in transcritical conditions for the SHW application has bring the attention of many researchers. This effort has been materialized in projects such as ECO-CUTE in Japan. Works like Rieberer et al., (1997), Nekså et al., (1998), Nekså (2002), and Cecchinato et al., (2005) has shown high efficiency of these cycles at high temperature lifts, as for instance in heating water from $10^{\circ} \mathrm{C}$ to $60^{\circ} \mathrm{C}$ or even higher temperatures, showing the transcritical $\mathrm{CO}_{2}$ cycle as a viable alternative to the synthetic working fluids. These authors agree with the requirement of using stratified storage tanks to keep warm water separated from the cold water entering from the town, in order to achieve a good energy performance. Pitarch et al., (2014) compared in a theoretical study the COP penalty of different heat pump systems $\left(\mathrm{CO}_{2}\right.$ cycle with different subcritical refrigerants working at subcooling zero) for SHW production when the inlet water temperature changes (Figure 1). This study shows a higher $\mathrm{COP}$ for the $\mathrm{CO}_{2}$ cycle for high water temperatures lift, while after a certain value of the inlet water temperature, COP is higher for the subcritical systems. Transcritical cycles also depends critically on the optimal control of cycle internal variables like the gas cooler pressure. In the last decade several authors have been studying the optimization of such a system, Kauf(1999), Chen and Gu, (2005), and Sarkar et al., (2004). 


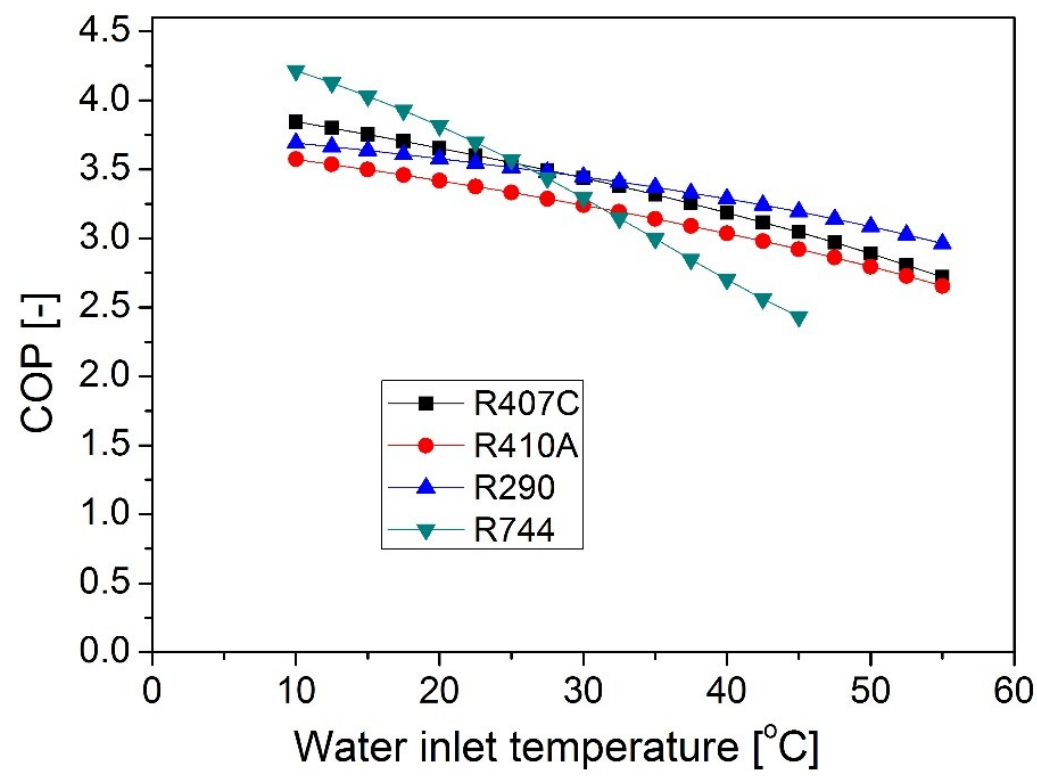

Figure 1: COP dependency with water inlet temperature for different refrigerants, water outlet temperature $60^{\circ} \mathrm{C}$. (Pitarch et al., 2014)

In addition to $\mathrm{CO}_{2}$, also another natural fluid, Propane, has been investigated by several researchers for the SHW application. A report by IEA (IEA, Annex 32) shows the seasonal performance of a Propane Heat Pump for the combined space heating and SHW production in a Norwegian passive house. In another report, Justo Alonso and Stene (2010) compares the theoretical calculated COP of a $\mathrm{CO}_{2}$ transcritical cycle with two different systems working with propane, with and without subcooler. They concluded that COP is $20 \%$ higher when $\mathrm{CO}_{2}$ is used, due to the advantage of $\mathrm{R} 744$ at high water temperature glides, which entails a high temperature glide in the refrigerant side too, improving the heat rejection process at gas cooler. The two different systems working with propane studied by Justo Alonso and Stene (2010) were one with subcooling zero, and the other with a subcooler. They showed an increase of COP for the Propane cycle working with subcooler respect to the one with no subcooling, although they do not say the degree of subcooling.

Other researchers have concerned about subcooling, Corberan et al., 2008 and Corberan et al., 2011, studied from the theoretical and experimental point of view the role of the charge in the system, and pointed out that an optimum charge (and consequently a subcooling) exists for a given external condition. For the case of a non-natural fluid there are also some works concerning subcooling, Choi \& Kim, (2004), Redón et al., (2014), Cecchinato et al., (2005). Cecchinato et al., (2005) compares theoretically a $\mathrm{CO}_{2}$ transcritical cycle with R134a subcritical cycle working with subcooling. They pointed out that it is possible to increase the energy efficiency 
of the R134a cycle with an increase of subcooling. In this way, the results for SHW production are similar for both cycles in winter conditions, while $\mathrm{CO}_{2}$ has a higher performance in summer.

Nevertheless, up to the knowledge of the authors, there are not any publication studying the advantage of making subcooling in subcritical systems in order to take profit from the high water temperature lift in the SHW application (around $50 \mathrm{~K}$ ). The works commented above reported a higher system efficiency working with certain subcooling, but always at low water temperature lift where usually the optimum subcooling is found between $5 \mathrm{~K}$ and $10 \mathrm{~K}$.

Nevertheless, up to the knowledge of the authors, no experimental results of subcritical systems working with subcooling for the SHW production are published, but from the few theoretical works there are enough evidence to believe that this kind of cycles can work with high efficiency for this application. For instance, Cecchinato et al., (2005) compares theoretically a CO2 transcritical cycle with R134a subcritical cycle working with subcooling. They pointed out that it is possible to increase the energy efficiency of the R134a cycle with an increase of subcooling. In this way, the results for SHW production are similar for both cycles in winter conditions, while $\mathrm{CO} 2$ has a higher performance in summer. In this sense,

Propane is a good candidate for subcooling, not only due to its good environmental properties, but also due to thermodynamic ones. Propane has a high specific heat in liquid state compared to other refrigerants, like with R134a, so it takes profit from doing subcooling (Lemmon et al., 2007). Another characteristic of propane, is that it can work at high evaporating temperatures, hence it is a good solution for the waste heat recovery, Schmid (2009) pointed out that $15 \%$ of the thermal energy provided to the building is lost, unused, via the sewage system.

The scope of the present paper is to evaluate the performance of a Propane water-to-water heat pump prototype for SHW production, in the application of heat recovery from any water source, for instance from sewage water or a condensation loop. The prototype is able to overcome high subcooling in order to take profit of the high water temperature lift in the SHW application. First, the refrigerant cycle in order to achieve the needed subcooling and the experimental layout used in the laboratory are presented. Finally, the experimental results for $\mathrm{COP}$, heating capacity and other important parameters at different temperatures water source at the condenser and evaporator are shown.

\section{HEAT PUMP PROTOTYPE}


This prototype was designed and built in order to study a heat pump booster for waste heat recovery trying to exploit the advantage of the low inlet water temperature to produce subcooling and improve COP, the used refrigerant is the natural fluid Propane. The waste heat could come from any available source of energy, such as sewage water or a condensation loop, which temperatures usually goes between $10^{\circ} \mathrm{C}$ and $35^{\circ} \mathrm{C}$. This heat pump produces sanitary hot water at $60^{\circ} \mathrm{C}$ and it was tested at different condenser water inlet temperatures in order to study the influence of the water temperature lift with the performance of the heat pump, from $10^{\circ} \mathrm{C}$ to $55^{\circ} \mathrm{C}$. Propane has been selected, not only by its good environmental performance, but also by thermodynamic reasons. Propane is able to provide good efficiency at low pressure ratios with a low discharge temperature, and it has a high specific heat in liquid state. The system was designed to obtain around $50 \mathrm{~kW}$ in the nominal point, i.e. $20^{\circ} \mathrm{C}$ at the water inlet evaporator and producing sanitary hot water at $60^{\circ} \mathrm{C}$ from an inlet temperature of $10^{\circ} \mathrm{C}$.

\subsection{Heat Pump refrigerant cycle}

Figure 2 shows the scheme of the water-to-water heat pump prototype with subcooler. A liquid receiver located right after the condenser ensures that (at steady state conditions) the refrigerant leaves the condenser in liquid saturated state (point 3), the liquid receiver is big enough to fulfil this condition for all test conditions. For continuity the refrigerant leaves the liquid receiver at the saturation condition, at the condenser saturation temperature, which value for this application is around $58^{\circ} \mathrm{C}$. Thereafter, the refrigerant is subcooled in a heat exchanger (HX) specially designed for this reason (subcooler). In the water side, it passes first through the subcooler, where it is preheated before passing through the condenser, where the water reaches the target temperature for the SHW application (usually $60^{\circ} \mathrm{C}$ ). 

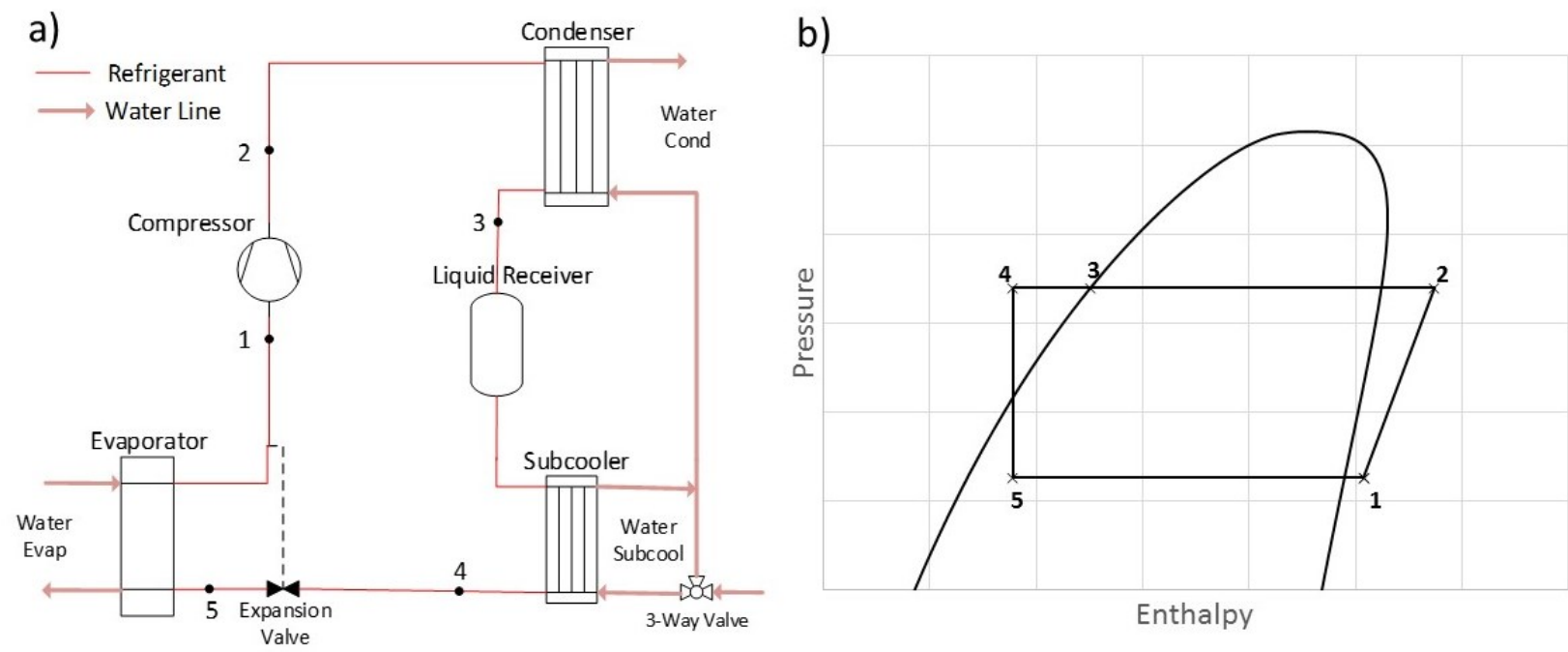

Figure 2: Heat Pump subcooler in series with condenser a) Scheme, b) P-h diagram.

The subcooler was selected in order to obtain a low difference temperature between the water inlet and refrigerant outlet. Therefore the maximum possible subcooling for this cycle was obtained at each condition, where subcooling will depend on the water inlet temperature. With this configuration, it was possible to obtain a great subcooling for high water temperature lift, which improve the heat rejection process. Figure 3 shows the theoretical temperature profile for the water and refrigerant (Propane) at the condenser, with and without subcooling (Tammaro et al., 2015). It can be seen a better temperature matching between refrigerant and water along the heat exchanger area when subcooling is produced.

Inlet water temperatures at the subcooler depends on the city water temperature, which usually ranges between $10^{\circ} \mathrm{C}$ to $30^{\circ} \mathrm{C}$ depending on location and period of the year. But it also depends on the water tank connection and sizing, making possible to have higher inlet water temperatures, for instance, when recovering heat losses at the tank in periods of inactivity, then water temperature at the inlet of subcooler can reach $55^{\circ} \mathrm{C}$. For this reason, experiments with water inlet temperatures to the subcooler ranging from $10^{\circ} \mathrm{C}$ to $55^{\circ} \mathrm{C}$ were done. This variation in the inlet water temperature implies a big variation on the water mass flow rate if a constant water temperature of $60^{\circ} \mathrm{C}$ is being produced. The higher the water mass flow rate, the higher the pressure drop at the components. Subcooler has lower cross sectional area than condenser, since it was designed for refrigerant liquid, producing higher pressure drops in the water side. In order to reduce consumption from the auxiliary components such as the water pump, part of the water mass flow was bypassed at the subcooler, keeping the pressure drop in the water side lower than 0.4 bar. The partial bypass was only necessary for high inlet water temperature (more than $50^{\circ} \mathrm{C}$ ), and was controlled by a three way valve. 


\subsection{Heat Pump Design}

The different components were designed in order to reach the high subcooling at the separate heat exchanger. Since refrigerant density is higher at subcooler than at condenser, subcooler size can be optimized for refrigerant liquid, so it has an appropriate refrigerant velocity for heat transfer. In this way, subcooler had less plates and smaller plate pitch than at the condenser.

The liquid receiver has a volume of 7 liters to ensure the compensation of refrigerant volume variations between the different measurements conditions. The total charge of the system is $6.4 \mathrm{~kg}$ of Propane. One should notice that the total charge of the system and LR volume could be further reduce if the operating range is narrowed down, since this volume was selected in order to fulfill very different conditions.

Table 1 shows the characteristics of the different components of the Propane cycle.

\begin{tabular}{lcc}
\hline \multicolumn{1}{c}{ Component } & Type & Size \\
\hline Compressor & Scroll (2900 rpm) & $29.6 \mathrm{~m}^{3} \mathrm{~h}^{-1}$ \\
Condenser & BPHE Counterflow & $3.5 \mathrm{~m}^{2}$ \\
Subcooler & BPHE Counterflow & $0.87 \mathrm{~m}^{2}$ \\
Evaporator & BPHE Counterflow & $6 \mathrm{~m}^{2}$ \\
Liquid Receiver & - & $7 \mathrm{I}$ \\
Expansion Valve & Electronic EV & $5-60 \mathrm{~kW}$ \\
\hline
\end{tabular}

Table1. Components of the heat pump prototype

\section{TEST CAMPAIGN}

\subsection{Experimental setup}

Figure 3 shows the test rig, which allows to test water-to-water heat pumps with a heating capacity up to 70 $\mathrm{kW}$. Between the dashed lines it is the unit to be tested, where points 1'\&2' are the inlet/outlet for the heat sink (demand side), and 3'\&4' are the inlet/outlet for the heat source (waste heat side). The test rig is able to keep to a constant value the water temperature at these points. In order to ensure a steady state behavior, all the measured points were checked to lie under the limits marked by the norm UNE-EN 14511-3.

Besides the main Propane refrigerant loop cycle (between dashed line), the test rig consists of four loops:

a) The water loop for the source (Evaporator). Simulates the heat recovery from a water source.

b) The water loop for the heat sink (Condenser). Simulates the SHW production.

c) The water/glycol loop.

d) The chiller. Works with R410A 
The temperature of the water at the evaporator was recovered through a heat exchanger that interacted with the sink heat loop and an electrical heater added extra heat if it is necessary. Therefore, the temperature of the water at the outlet of the condenser it was cooled in part, due to the recovery heat exchanger with the evaporating water loop. The rest of heat that needed to be rejected in order to reestablish the water inlet temperature at the subcooler, was pumped out to the ambient with a chiller, which was connected to the water condensing loop through a water/glycol loop. Components such as 3-way valves or pumps with variable frequency drive, were controlled by means of PIDs in order to reach the target inlet and outlet water temperatures.

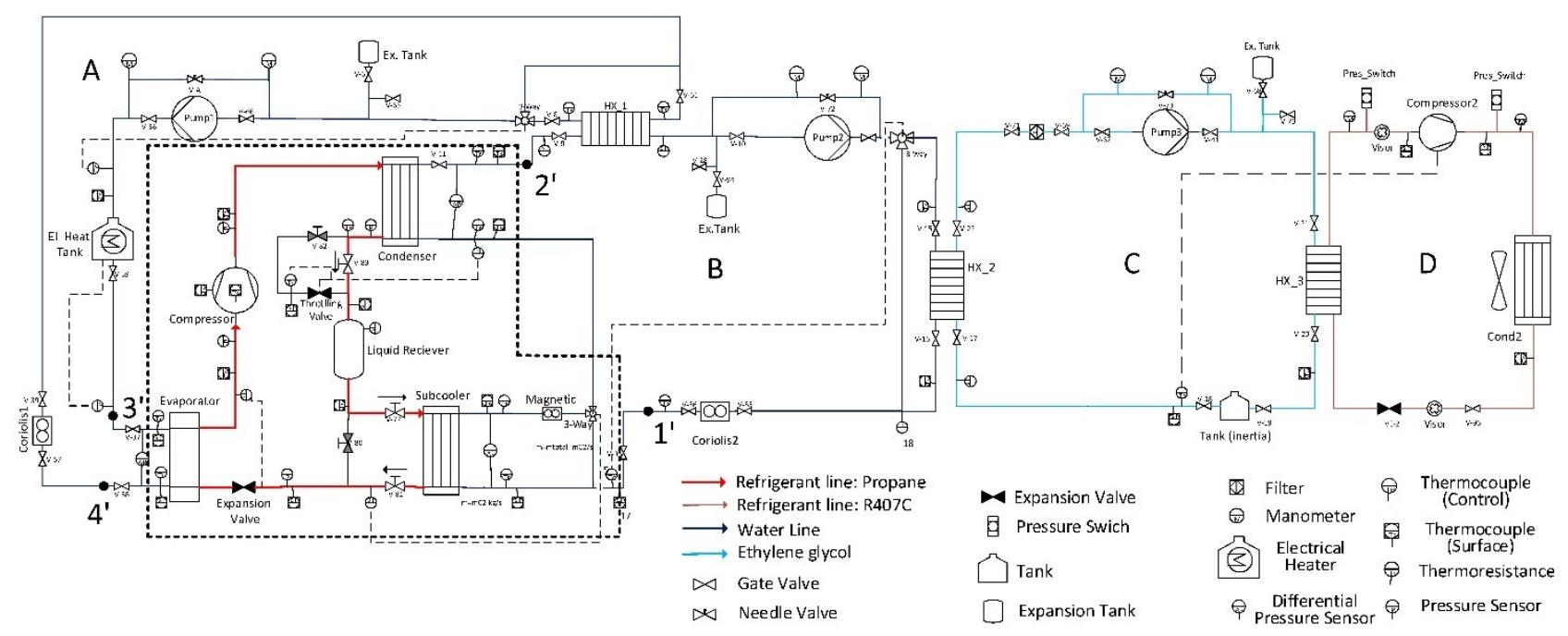

Figure 3: Overview scheme of the Test Rig with sensors

Regarding to the security issues related with the use of Propane, the laboratory is equipped with gas sensors and an alarm system able to detect a propane leakage and start with a security routine. If commercialized, these heat pump will be installed in a ventilated place outdoor.

The capacities of the heat pump were measured in the water side in order to measure it as accurate as possible, six thermoresistances were located at inlet/outlet of heat exchangers directly in contact with the water. To monitor and measure temperature in other points, a total number of $27 \mathrm{~T}$-type thermocouples were used. The water mass flow through evaporator and condenser were measured with Coriolis mass flow meters. For control reasons, a magnetic mass flow meter was measuring the water mass flow through subcooler, which in most of the cases was the same as in the condenser. For the pressure probes at the refrigerant side there were 3 high accuracy Rosemount sensors. In the water side there were 3 differential pressure sensors to measure the pressure drop in the heat exchangers. With these measurements and according to the European Standard 14511- 
3, the auxiliary consumption of the water pumps was calculated. In order to control the system and measure those key parameters to evaluate the performance of the heat pump, all the sensors were connected to a data acquisition system “Agilent 34970A”, where all parameters were monitored.

Table 2 shows the main sensors with the relative and absolute uncertainty intrinsic to the sensor. The total uncertainties of the main measured parameters can be seen in the annexed material Annex A, which includes the intrinsic uncertainty of the sensors, the acquisition data, and standard deviation of the mean value, which was calculated from the measured sequence during 30 minutes. For the calculated parameters such as heating COP, the equation of propagating error was used (Coleman and Steele).

\begin{tabular}{|c|c|c|c|c|}
\hline Magnitude & Model & Relative uncertainty & $\begin{array}{l}\text { Absolute } \\
\text { uncertainty }\end{array}$ & Units \\
\hline \multirow{6}{*}{ Pressure } & $\begin{array}{c}\text { Differential 1151 Smart } \\
\text { Rosemount }\end{array}$ & $0.1256 \%$ of Span & $4.684 E-04$ & bar \\
\hline & Differential P Siemens Sitrans $P$ & $0.1417 \%$ of Span & $3.542 E-04$ & bar \\
\hline & Differential P Setra & $0.25 \%$ of Span & $1.723 E-03$ & bar \\
\hline & P 1151 Smart GP7 Rosemount & $0.1239 \%$ of Span & $2.602 E-02$ & bar \\
\hline & P 1151 Smart GP8 Rosemount & $0.1547 \%$ of Span & $7.889 E-02$ & bar \\
\hline & P 3051 TG3 Rosemount & $0.1351 \%$ of Span & $3.782 E-02$ & bar \\
\hline \multirow{2}{*}{ Temperature } & Thermocouple T Type & & 1 & $K$ \\
\hline & $R T D$ & & 0.06 & $K$ \\
\hline \multirow{2}{*}{ Flow } & $\begin{array}{c}\text { Coriolis SITRANS F C MASS } \\
2100\end{array}$ & $\begin{array}{l}0.29 \% \text { of } \\
\text { Reading }\end{array}$ & & \\
\hline & $\begin{array}{c}\text { Magnetic SITRANS FM } \\
\text { MAG5100 W }\end{array}$ & $\begin{array}{l}0.36 \% \text { of } \\
\text { Reading }\end{array}$ & & \\
\hline Power & DME 442 & $0.3 \%$ of Reading & & \\
\hline
\end{tabular}

\subsection{Performed Test}

The boundary conditions are defined by the kind of application. In this case for SHW, it was selected production at $60^{\circ} \mathrm{C}$. The inlet water temperature to the subcooler ranged from $10^{\circ} \mathrm{C}$ to $55^{\circ} \mathrm{C}$ due to the different specifications it can have depending on the water tank selection, size and type (stratified). For those points where pressure drop at the subcooler (water side) was higher than 0.4 bar, it was partially bypassed, usually for inlet water temperatures higher than $50^{\circ} \mathrm{C}$.

In the evaporator, the inlet water temperature ranged from $10^{\circ} \mathrm{C}$ to $35^{\circ} \mathrm{C}$, which corresponds for a waste heat recovery application. The water mass flow through the evaporator was adjusted in order to obtain a $5 \mathrm{~K}$ water temperature decrease at the nominal point, i.e. from $20^{\circ} \mathrm{C}$ to $15^{\circ} \mathrm{C}$. The water mass flow rate adjusted in the 
nominal point was kept constant for the rest of test points (approximately $7000 \mathrm{~kg} \mathrm{~h}^{-1}$ ), this procedure is described in the European Standard EN 14825. In the refrigerant side, superheat was kept constant to 10K for all measured points.

Once all the target parameters were reached, the acquisition data recorded data every 10 seconds during 30 minutes in order to ensure a stable condition. Table 3 contains the measured points. The COP and heating capacity were calculated at each point according to the European Standard 14511-3, these calculations include the auxiliary consumption of the water pumps as it is indicated in the previous standard.

\begin{tabular}{|c|c|c|c|}
\hline $\begin{array}{c}\text { Water in Evaporator } \\
\text { Temperature }\left[{ }^{\circ} \mathrm{C}\right]\end{array}$ & $\begin{array}{c}\text { Water in Subcooler } \\
\text { Temperature }\left[{ }^{\circ} \mathrm{C}\right]\end{array}$ & $\begin{array}{c}\text { Water out Condenser } \\
\text { Temperature }\left[{ }^{\circ} \mathrm{C}\right]\end{array}$ & $\begin{array}{c}\text { Mass flow ratio*: } \\
\dot{m}_{w, s u b} / m_{w, \text { cond }}\end{array}$ \\
\hline \multirow{6}{*}{10} & 10 & \multirow{29}{*}{60} & 1.00 \\
\hline & 20 & & 1.00 \\
\hline & 30 & & 1.00 \\
\hline & 40 & & 1.00 \\
\hline & 50 & & 0.83 \\
\hline & 55 & & 0.45 \\
\hline \multirow{6}{*}{20} & 10 & & 1.00 \\
\hline & 20 & & 1.00 \\
\hline & 30 & & 1.00 \\
\hline & 40 & & 1.00 \\
\hline & 50 & & 0.67 \\
\hline & 55 & & 0.30 \\
\hline \multirow{6}{*}{25} & 10 & & 1.00 \\
\hline & 20 & & 1.00 \\
\hline & 30 & & 1.00 \\
\hline & 40 & & 1.00 \\
\hline & 50 & & 0.63 \\
\hline & 55 & & 0.29 \\
\hline \multirow{6}{*}{30} & 10 & & 1.00 \\
\hline & 20 & & 1.00 \\
\hline & 30 & & 1.00 \\
\hline & 40 & & 1.00 \\
\hline & 50 & & 0.53 \\
\hline & 55 & & 0.29 \\
\hline \multirow{5}{*}{35} & 20 & & 1.00 \\
\hline & 30 & & 1.00 \\
\hline & 40 & & 1.00 \\
\hline & 50 & & 0.45 \\
\hline & 55 & & 0.26 \\
\hline
\end{tabular}

Table 3: Test matrix with a total number of 29 measured points. ${ }^{*}$ Water mass flow ratio between subcooler and condenser 


\section{RESULTS}

Figure 4 shows the heating COP and heating capacityaccounting with auxiliary consumption. For a given inlet water temperature at the evaporator $\left(\mathrm{T}_{\mathrm{w}, \mathrm{e}}\right)$ it can be seen a linear relationship between the water inlet temperature at the subcooler $\left(\mathrm{T}_{\mathrm{w}, \mathrm{c}}\right)$ and the heating $\mathrm{COP}$, which decreases as the $\mathrm{T}_{\mathrm{w}, \mathrm{ci}}$ increase. The linear fitting adjusted to the experimental values, although the points corresponding to $10^{\circ} \mathrm{C}$ and $55^{\circ} \mathrm{C}$ were slightly overpredicted in all the cases the error is lower than $2 \%$. The slope of the linear fitting slightly increased as the water inlet temperature to the evaporator increase. For the nominal water inlet temperature at the evaporator $\left(20^{\circ} \mathrm{C}\right)$, heating COP decreased about $35 \%$ when passing from an inlet water temperature at the subcooler of $10^{\circ} \mathrm{C}$ to $55^{\circ} \mathrm{C}$. This linearity was also observed for a given water inlet temperature at the subcooler and changing the water temperature at the evaporator. In this case, heating COP increased as the temperature at the inlet evaporator increased, which was directly related with the increase of the evaporating pressure. When it passed from 10 to $30^{\circ} \mathrm{C}, \mathrm{COP}$ increased about $49 \%\left(\mathrm{~T}_{\mathrm{w}, \mathrm{ci}}=10^{\circ} \mathrm{C}\right)$. The maximum measured heating COP was around 6.8, while at the nominal point $\left(\mathrm{T}_{\mathrm{w}, \mathrm{e}}=20^{\circ} \mathrm{C} ; \mathrm{T}_{\mathrm{w}, \mathrm{c}}=10^{\circ} \mathrm{C}\right) \mathrm{COP}$ was 5.61 .

Regarding to heating capacity, it had a similar behavior than the heating COP. The maximum measured capacity was about $63.4 \mathrm{~kW}$, and at nominal conditions was $47.1 \mathrm{~kW}$. For the nominal water inlet temperature at the evaporator, $20^{\circ} \mathrm{C}$, heating capacity decreased about $25 \%$ when passing from an inlet water temperature at the subcooler of $10^{\circ} \mathrm{C}$ to $55^{\circ} \mathrm{C}$. As in the heating $\mathrm{COP}$, capacity increased as the temperature at the inlet evaporator increased, which is directly related with the increase of the evaporating pressure. When it passed from $10^{\circ} \mathrm{C}$ to $30^{\circ} \mathrm{C}$, capacity increased about $66 \%\left(\mathrm{~T}_{\mathrm{w}, \mathrm{ci}}=10^{\circ} \mathrm{C}\right)$.
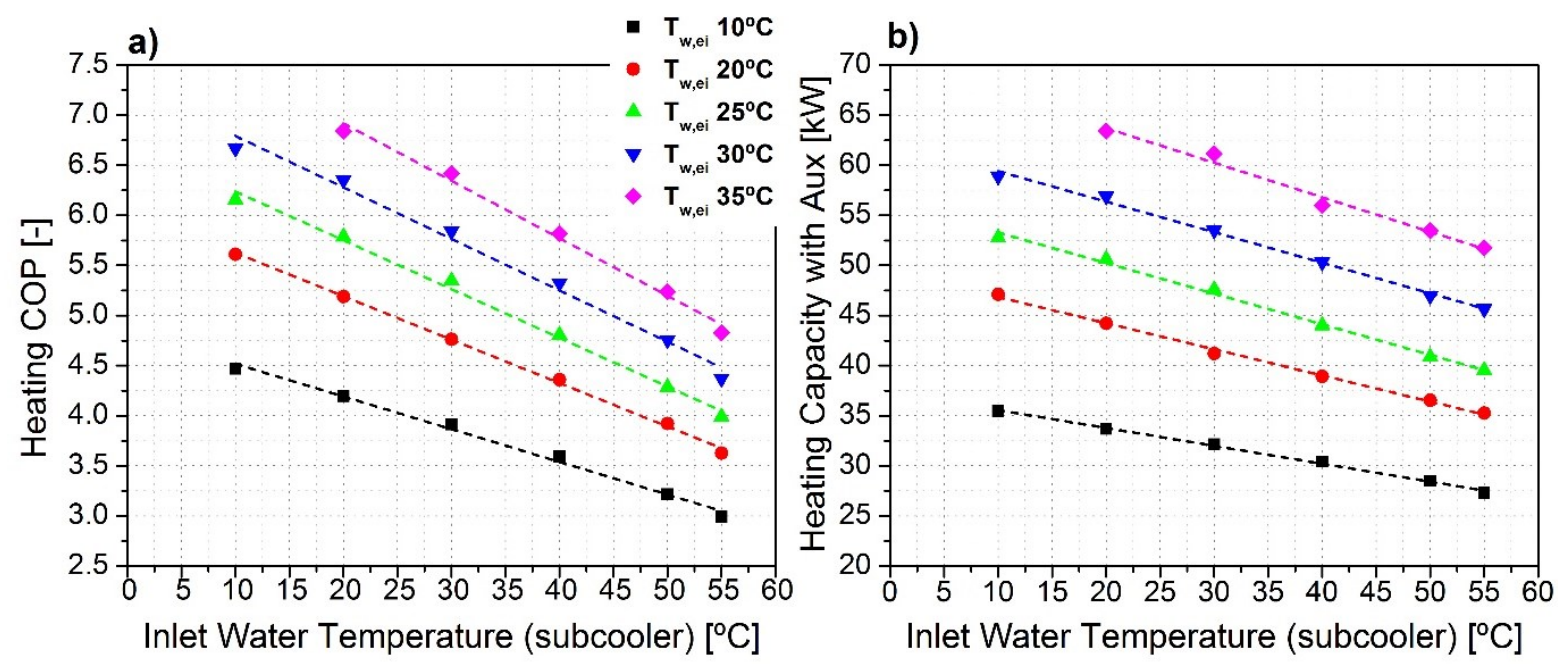

Figure 4: a) Heating COP, b) Heating capacity vs. inlet water temperature to subcooler for different water inlet temperature to evaporator $\left(\mathrm{T}_{\mathrm{w}, \mathrm{co}}=60^{\circ} \mathrm{C}\right)$. 
Figure 5a) compares the heating COP results accounting with auxiliary consumption for the cycle working with subcooling against the results obtained with a cycle working without subcooling, and the same boundary conditions $\left(\mathrm{T}_{\mathrm{w}, \mathrm{e}}=20^{\circ} \mathrm{C}\right)$. The highest improvement was about $31 \%$, which corresponds to the highest water temperature lift $\left(\mathrm{T}_{\mathrm{w}, \mathrm{c} i}=10^{\circ} \mathrm{C}\right)$, with a subcooling of $43.9 \mathrm{~K}$. As the inlet water temperature to the subcooler increased, the COP difference between subcooled and non-subcooled cycle decreased, having an improvement about $6.8 \%$ for a water temperature lift of $5 \mathrm{~K}\left(\mathrm{~T}_{\mathrm{w}, \mathrm{c}}=55^{\circ} \mathrm{C}\right)$, which had a subcooling of $8.6 \mathrm{~K}$. Therefore, the highest improvement produced by adding subcooling was at high water temperature lift, since it is here where subcritical cycles working without subcooling had the worst water/refrigerant temperature match, and by adding subcooling made a great difference in the heat transfer process. One should remember that in this prototype, subcooling was made in a separate heat exchanger from the condenser, so condenser was exclusively used for condensing in all measured points.

Figure 5b) shows the comparison for condensing saturation temperature for the cycle working with subcooling against the results obtained with a cycle working without subcooling, and the same boundary conditions $\left(\mathrm{T}_{\mathrm{w}, \mathrm{e}}=20^{\circ} \mathrm{C}\right)$. The condensing temperature was higher for the cycle working with subcooling, being this difference higher at high water temperatures lift, around $2^{\circ} \mathrm{C}$ more in the higher water temperature lift. For low water temperature lift $\left(\mathrm{T}_{\mathrm{w}, \mathrm{ci}}>50^{\circ} \mathrm{C}\right)$, the condensing temperature in both cases was quite similar. This behavior was related with the amount of subcooling, because, even though condenser is not being used for subcooling, the water is pre-heated at the subcooler before entering to the condenser, so the inlet water temperature at condenser is higher in than for the cycle working without subcooling. Finally, it can be conclude that the benefits obtained from producing subcooling are higher than the COP degradation due to the increase of condensing temperature.

Performance decreased as the water inlet temperature to the subcooler increased due to two reasons:

- Reduction of subcooling

- Increase of the condensing pressure 

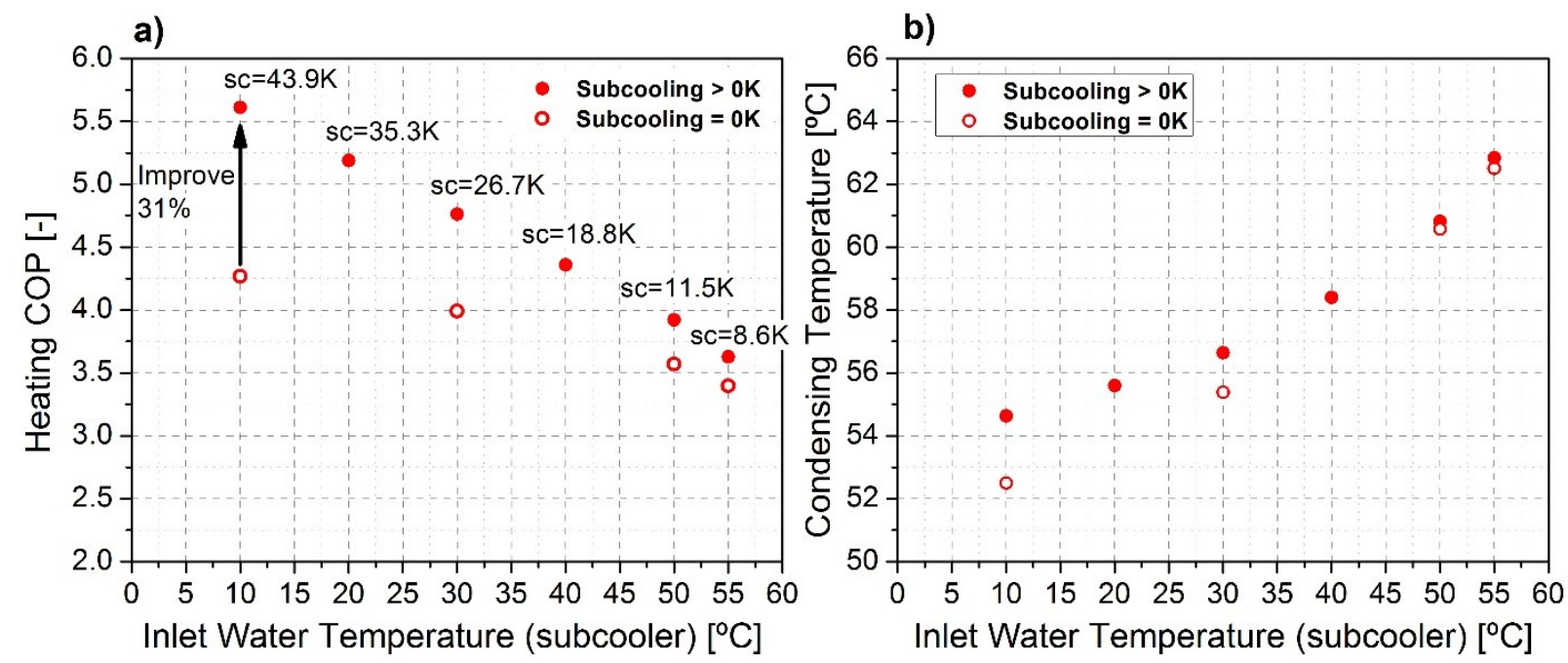

Figure 5: a) Heating COP, b) Condensing temperature vs. inlet water temperature to subcooler, with and without subcooling $\left(\mathrm{T}_{\mathrm{w}, \mathrm{co}}=60^{\circ} \mathrm{C}\right)$.

Figure 6a) shows the subcooling depending on the inlet water temperature at the subcooler. It can be seen a linear dependency, where the evaporating temperature had an insignificant influence. Subcooling was directly related with the refrigerant outlet temperature at the subcooler, which was quite close to the water inlet temperature. This means that the subcooler was able to produce the maximum subcooling at all conditions, even when subcooler was partially bypassed in the water side $\left(\mathrm{T}_{\mathrm{w}, \mathrm{ci}}>50^{\circ} \mathrm{C}\right)$. Subcooling went from $44 \mathrm{~K}$ at the lowest water inlet temperature to $9 \mathrm{~K}$ at an inlet water temperature of $55^{\circ} \mathrm{C}$.

One particularity of this application with high subcooling and high evaporating temperatures, was the low refrigerant quality at the evaporator inlet, or even subcooled liquid. Figure $6 b$ ) shows the inlet refrigerant quality at the evaporator, where negative values means subcooled refrigerant. It had a linear dependency with the inlet water temperature at the subcooler, which was related with subcooling, higher subcooling leads to lower refrigerant quality. The refrigerant quality also depended on the evaporator conditions, higher inlet water temperatures at the evaporator leaded to lower refrigerant qualities. It can be seen that for the lowest quality values, refrigerant was at subcooled state at the evaporator inlet, and, hence at the expansion valve outlet. On the other hand, the highest refrigerant quality was about 0.4 . These big variations in the inlet quality could lead to high variation on the refrigerant mass contained in the evaporator, which needs to be taken into account in the design process of such a systems. 

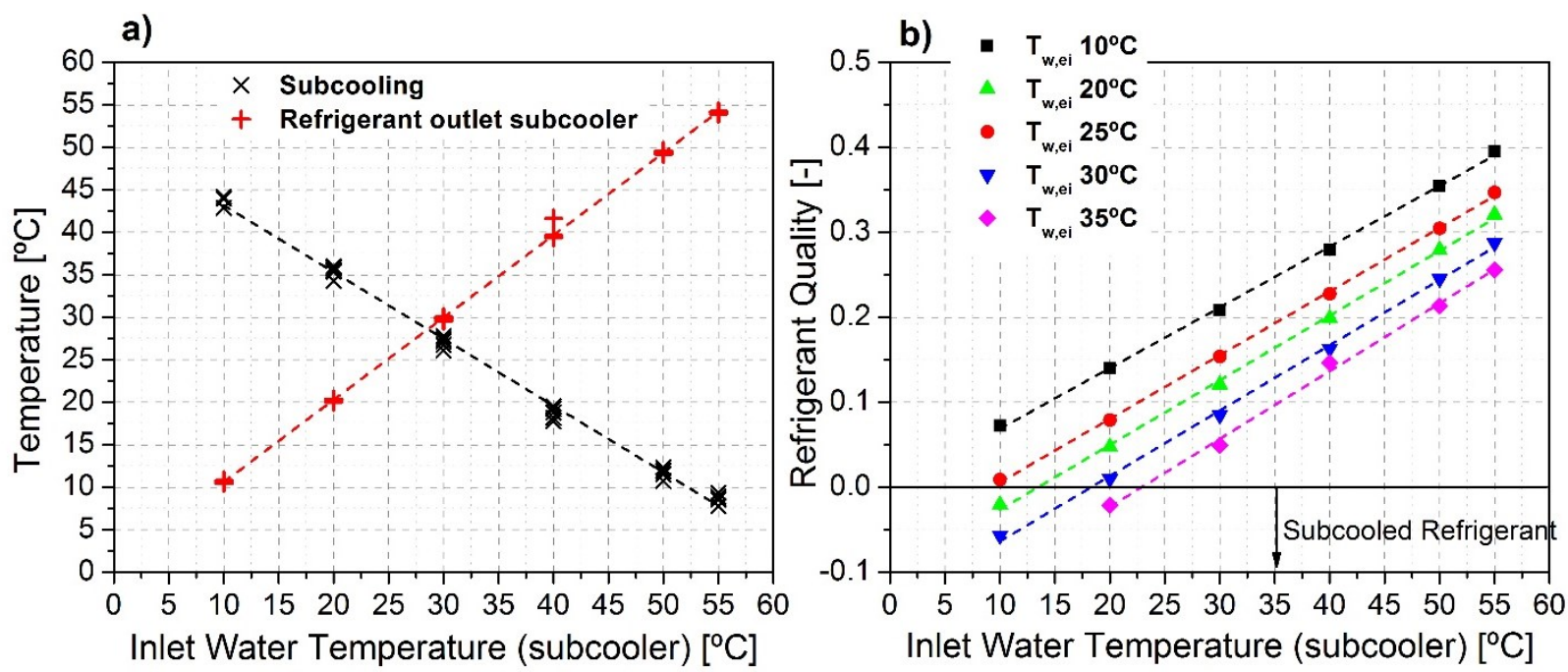

Figure 6: a) Subcooling and refrigerant temperature at subcooler outlet, b) Refrigerant quality at inlet evaporator vs. inlet water temperature to subcooler for different water inlet temperature to evaporator $\left(\mathrm{T}_{\mathrm{w}, \mathrm{co}}=\right.$ $\left.60^{\circ} \mathrm{C}\right)$

The system has been working stable at all conditions, even at low refrigerant inlet quality at the evaporator. Nevertheless, preliminary thermography studies revealed a different refrigerant distribution depending on if refrigerant quality was lower than 0 (subcooled refrigerant) or not (Figure 7). When inlet quality was low $\left(\mathrm{T}_{\mathrm{w}, \mathrm{c}}=10^{\circ} \mathrm{C}\right)$ it could be seen that liquid refrigerant accumulated at the HX channels closer to the refrigerant inlet, whereas for higher refrigerant quality $\left(\mathrm{T}_{\mathrm{w}, \mathrm{c} i}=30^{\circ} \mathrm{C}\right)$, refrigerant accumulateed at the HX channels farthest to the refrigerant inlet. For this reason, refrigerant quality must be taken into account for the evaporator design in this kind of systems, and further thermography studies should be done. 

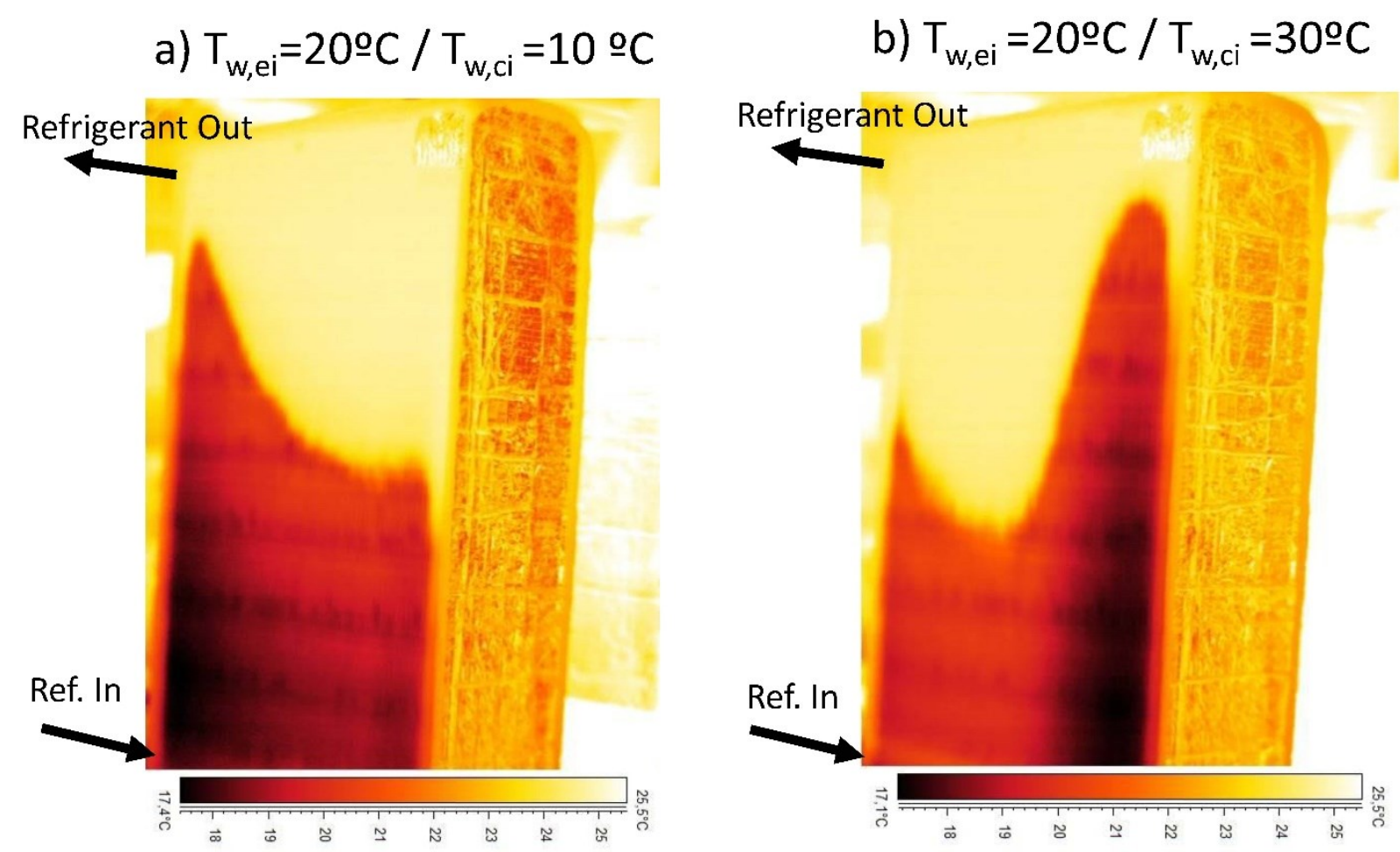

Figure 7: Thermography of evaporator a) Refrigerant inlet quality of -0.025 b) Refrigerant inlet quality of 0.14

Elevated evaporating temperatures also lead to high power consumption by the compressor, since refrigerant mass flow increases with evaporating pressure. Envelope for scroll compressors similar to the one used in this heat pump prototype is usually limited for evaporating temperatures up to $20^{\circ} \mathrm{C}$. During these test measurements the maximum evaporating temperature is about $24^{\circ} \mathrm{C}$, corresponding for the $\mathrm{T}_{\mathrm{w}, \mathrm{e}}=35^{\circ} \mathrm{C}$, but no breakdown or performance decrease has been observed in the compressor. The good reliability of the compressor at these conditions can be explained by the use of Propane, since the envelope of the used compressor is given for refrigerant R410A. While the density of Propane at the entrance of compressor for high evaporating temperatures is about $19.4 \mathrm{~kg} / \mathrm{m} 3$, the density for R410A at the same conditions will be 60.5 $\mathrm{kg} / \mathrm{m} 3$. This density difference is translated to a higher current demand at the compressor for the refrigerant R410A.

For more information about the measured points, like water mass flow rate and other important parameters, look at annex A. This annex, also contain some extra points with different SHW temperature production. Furthermore, the uncertainties of the important results are also given. 


\section{CONCLUSIONS}

Transcritical systems working with $\mathrm{CO} 2$ are normally used for SHW production due to its good performance at the high temperature lift. This paper presents the experimental results of a water-to-water heat pump booster prototype for SHW production using Propane as a refrigerant, and using subcooling in order to enhance the heat transfer process in a subcritical cycle. The main points derived from the present study have been:

- Heating COP is significantly improved by adding subcooling. The benefits obtained from producing subcooling are higher than the COP degradation due to the increase of condensing temperature.

- COP heating and heating capacity decrease linearly with the inlet water temperature at the subcooler $\left(\mathrm{T}_{\mathrm{w}, \mathrm{ci}}\right)$

- Subcooling depends mostly on the water inlet temperature to the subcooler, and not on the inlet water temperature to evaporator.

- The maximum subcooling is reached when refrigerant temperature at the subcooler outlet gets closer to $\mathrm{T}_{\mathrm{w}, \mathrm{ci}}$

- Low refrigerant quality or even subcooled liquid can be find at evaporator inlet with points working at elevated evaporating pressure and high subcooling.

- Non instability has been found working with refrigerant liquid at the evaporator inlet.

- Compressor holds performance after working with Propane at evaporating temperatures of $24^{\circ} \mathrm{C}$.

From all this work, it should be remarked that a subcritical cycle with Propane has demonstrate to have a good performance for sanitary hot water production when working with subcooling. At the nominal point, COP and heating capacity with auxiliary consumption are 5.61 and $47.1 \mathrm{~kW}$ respectively. While the maximum measured values are 6.8 and $63.4 \mathrm{~kW}$ for COP and capacity respectively. The corresponding performance increase due to the subcooling approach at the nominal point has been about $31 \%$.

\section{ACKNOWLEDGEMENTS}

This work has been developed in the 7 framework program of the European Union by the project Next Generation of Heat Pump Technologies (NEXTGHP) grant agreement 307169. The authors give 
thanks for the given support. Part of the work presented was carried by Miquel Pitarch-Mocholí with the financial support of the Phd scholarship from the Universitat Politècnica de València.

\section{REFERENCES}

Cecchinato, L., Corradi, M., Fornasieri, E., Zamboni, L., 2005. Carbon dioxide as refrigerant for tap water heat pumps: a comparison with the traditional solution. Int. J. Refrigeration 28(8), 1250-1258.

Chen, Y., Gu, J., 2005. The optimum high pressure for $\mathrm{CO}_{2}$ transcritical refrigeration systems with internal heat exchangers. International Journal of Refrigeration 28(8), 1238-1249.

Choi, J.M., Kim, Y.C., 2004. Influence of the expansion device on the performance of a heat pump using $\mathrm{R} 407 \mathrm{C}$ under a range of charging conditions. International Journal of Refrigeration 27, 378-384

Coleman, H.W., Steele, W.G., 1999. Experimentation and Uncertainty Analysis for Engineers (2nd ed.)John Wiley \& Sons, Inc., New York

Corberán, J.M., Martínez-Galván, I., Gonzálvez-Maciá, J., 2008. Charge optimization study of a reversible water-to-water propane heat pump. International Journal of Refrigeration 31, 716-726

Corberán, J.M., Martínez-Galván, I., Martínez-Ballester, S., Gonzálvez-Maciá, J., Royo-Pastor, R., 2011. Influence of the source and sink temperatures on the optimal refrigerant charge of a water-to-water heat pump. International Journal of Refrigeration 34, 881-892

ECO-CUTE project, http://www.r744.com/assets/link/enEX_ecocute.pdf, (05 of February of 2015)

European Directive 2009/28/EC Of The European Parliament And Of The Council. eur-lex.europa.eu

IEA Heat Pump Programme Annex 32, Systems concept. Integrated water-to-water propane heat pump installed in a passive house in Southern Norway. www.annex32.net/pdf/ Final_reports/System_Concepts_IEA_HPP_Annex32.pdf.

Justo Alonso, M., Stene, J., 2010. IEA Heat Pump Programme Annex 32. Umbrella Report, System Solutions, Design Guidelines. Prototype System and Field Testing.

Kauf, F., 1999. Determination of the optimum high pressure for transcritical $\mathrm{CO}_{2}$-refrigeration cycles. International Journal of Thermal Sciences 38(4), 325-330

Kim, M., Kim, M. S. \& Chung, J. D., 2004. Transient thermal behavior of a water heater system driven by a heat pump. Int. J. Refrig. 27, 415-421

Lemmon, E. W., Huber, M. L., \& McLinden, M. O. 2007. REFPROP: Reference fluid thermodynamic and transport properties. NIST standard reference database, 23(8.0).

Nekså, P., Rekstad, H., Zakeri, G.R., Schiefloe, P.A., 1998. CO2-heat pump water heater: characteristics, system design and experimental results. Int. J. Refrigeration 21(3), 172-179.

Nekså, P., 2002. $\mathrm{CO}_{2}$ heat pump systems. Int. J. Refrigeration 25 (4), 421-427

Pitarch. M., Navarro-Peris. E., Gonzálvez-Maciá. J., Montagud. C., Corberan. JM., 2014. Influence of Water Lift Temperature in Transcritical and Subcritical Refrigerants. In: VII Congreso Ibérico de Ciencias y Técnicas del Frío, Tarragona, Spain. 
Redón, A., Navarro-Peris, E., Pitarch, M., Gonzálvez-Macia, J., \& Corberán, J. M., 2014. Analysis and optimization of subcritical two-stage vapor injection heat pump systems. Applied Energy, 124, 231-240.

Rieberer, R., Kasper, G., Halozan, J., 1997. $\mathrm{CO}_{2}$-a Chance for once through Heat Pump Heaters, $\mathrm{CO}_{2}$ Technology in Refrigeration, Heat Pumps and Air Conditioning Systems. IEA Heat Pump Centre, Trondheim, Norway.

Sarbu, I., 2014. A review on substitution strategy of non-ecological refrigerants from vapour compressionbased refrigeration, air-conditioning and heat pump systems. Int. J. Refrigeration 46, 123-141.

Sarkar, J., Bhattacharyya, S., Ram Gopal, M., 2004. Optimization of a transcritical $\mathrm{CO}_{2}$ heat pump cycle for simultaneous cooling and heating applications. Int. J. Refrigeration 27, 830-838.

Schmid, F., 2009. Sewage water: interesting heat source for heat pumps and chillers. In: Energy-engineer FH, Swiss Energy Agency for Infrastructure Plants. Zürich, Switzerland. 


\section{LIST OF FIGURES}

Figure 1: COP dependency with water inlet temperature for different refrigerants, water outlet temperature $60^{\circ} \mathrm{C}$. (Pitarch et al., 2014)

Figure 2: Heat Pump subcooler in series with condenser a) Scheme, b) P-h diagram.

Figure 3: Overview scheme of the Test Rig with sensors

Figure 4: a) Heating COP, b) Heating capacity vs. inlet water temperature to subcooler for different water inlet temperature to evaporator $\left(\mathrm{T}_{\mathrm{w}, \mathrm{co}}=60^{\circ} \mathrm{C}\right)$.

Figure 5: a) Heating COP, b) Condensing temperature vs. inlet water temperature to subcooler, with and without subcooling $\left(\mathrm{Tw}, \mathrm{co}=60^{\circ} \mathrm{C}\right)$.

Figure 6: a) Subcooling and refrigerant temperature at subcooler outlet, b) Refrigerant quality at inlet evaporator vs. inlet water temperature to subcooler for different water inlet temperature to evaporator $\left(\mathrm{T}_{\mathrm{w}, \mathrm{co}}=\right.$ $\left.60^{\circ} \mathrm{C}\right)$.

Figure 7: Thermography of evaporator a) Refrigerant inlet quality of -0.025 b) Refrigerant inlet quality of 0.14 